\title{
Miskonsepsi Matematika Mahasiswa PGSD Pada Penyelesaian Operasi Hitung Bilangan Bulat
}

\author{
Awal Nur Kholifatur Rosyidah*1, Mohammad Archi Maulyda ${ }^{2}$, Itsna Oktaviyanti ${ }^{3}$ \\ ${ }^{1,2,3}$ Program Studi Pendidikan Guru Sekolah Dasar, Fakultas Keguruan dan Ilmu Pendidikan, \\ Universitas Mataram, Indonesia \\ e-mail: *1awal_rosyidah@unram.ac.id, 2archimaulyda@unram.ac.id,
}

\begin{abstract}
ABSTRAK
Penelitian ini merupakan penelitian deskriptif kualitatif yang bertujuan untuk mendeskripsikan jenis-jenis miskonsepsi yang dilakukan mahasiswa PGSD sebagai calon guru Sekolah Dasar dalam menyelesaikan operasi hitung bilangan bulat. Miskonsepsi digolongkan menjadi 3 jenis yaitu Careless errors (Ca), Concept errors (Co), serta Careless errors dan Concept errors (Ca an Co). Peneliti memberikan 6 butir soal operasi hitung bilangan bulat kepasa 45 mahasiswa PGSD kelas $3 E$ yang menempuh mata kuliah Pembelajaran Matematika SD. Hasil penelitian menunjukkan bahwa $10 \%$ mahasiswa melakukan miskonsepsi jenis Careless errors (Ca) dalam menyelesaikan operasi penjumlahan dan pengurangan bilangan bulat. 53\% dengan persentase tertinggi (24 mahasiswa) melakukan miskonsepsi jenis Concept error (Co) dalam menyelesaikan operasi pengurangan bilangan bulat negatif dengan positif dan negatif dengan negatif. Serta ada 4 mahasiswa dengan persentase sebesar $9 \%$ dari total enam soal yang diberikan melakukan miskonsepsi jenis Careless and Concept error (Ca and Co) di dalam menyelesaikan operasi hitung pengurangan bilangan bulat yang sejenis, yaitu negatif dengan negatif maupun positif dengan positif.
\end{abstract}

Kata kunci: miskonsepsi, matematika, bilangan bulat

\begin{abstract}
This research is a qualitative descriptive study, that aims to describe the types of misconceptions conducted by PGSD students as prospective elementary school teachers in completing integer count operations. Misconceptions are classified into 3 types namely Careless errors (Ca), Concept errors (Co), and Careless errors and Concept errors ( $\mathrm{Ca}$ an $\mathrm{Co}$ ). The researcher gave 6 items of integer operation counts to 45 grade $3 E$ PGSD students taking elementary mathematics learning courses. The results showed that $10 \%$ of students made misconceptions of Careless errors $(\mathrm{Ca})$ in completing addition and subtraction integer operations. $53 \%$ with the highest percentage (24 students) doing the concept error (Co) misconception in completing the negative integer reduction operation with positive and negative with negative. And there are 4 students with a percentage of $9 \%$ from a total of six questions given to do the Careless and Concept error ( $\mathrm{Ca}$ and $\mathrm{Co}$ ) misconceptions in completing the arithmetic operations of reducing integers of the same type, namely negative with negative or positive with positive.
\end{abstract}

Keywords: misconceptions, mathematics, integers

\section{PENDAHULUAN}

Menjadi penting bagi setiap individu untuk belajar matematika mulai dari tingkatan sekolah dasar sampai perguruan tinggi. Bahkan untuk melakukan aktivitas keseharian, tidak dapat dipisahkan dari peranan matematika. Ada beberapa kompetensi yang menjadi catatan penting dalam pembelajaran matematika, yaitu sebagai 1) kegiatan penelusuran pola dan hubungan; 2) pengembangan kreativitas, intuisi, dan penemuan; 3) kegiatan berkomunikasi dan interaksi sosial; serta 4) pemecahan masalah[1]. Mengacu pada pendapat tersebut, yang menjadi fokus pada pembelajaran matematika adalah pemahaman individu atau pembelajar terhadap konsep matematika itu sendiri.

Mahasiswa PGSD sebagai praktisi atau calon guru sekolah dasar perlu mengetahui dan memahami objek yang akan diajarkan. Satu dari banyak cara yang dapat dilakukan adalah mengajarkan objek langsung pengajaran matematika. Setiap objek langsung pengajaran matematika mewakili tingkat kesulitan yang menuntut kemampuan kognitif yang berbeda-beda. Orientasi matematika yang hanya menghafal rumus akan mengakibatkan kemampuan 
mahasiswa dalam memecahkan masalah menjadi kurang terasah [2]. Maka dalam hal ini harus dipastikan bahwa mahasiswa PGSD paham terhadap semua kompetensi ajar. Hanya dengan memahami fakta, konsep, dan prinsip yang dipelajari maka mahasiswa akan memiliki keterampilan prosedural dalam menyelesaikan soal matematika.

Mata kuliah Pembelajaran matematika di SD dimaksudkan untuk membekali mahasiswa dengan kemampuan berpikir logis, analistis, sistematis, kritis, dan kreatif melalui pengembangan muatan setiap kompetensi. Kompetensi matematika sekolah meliputi bilangan dan operasinya, aljabar, pecahan, geometri, pengukuran, serta pengolahan data. Berdasarkan kompetensi tersebut, memberikan penekanan pada penguasaan bilangan dan operasi hitungnya. National Council of Teachers of Matehmatics (NCTM), menjelaskan bahwa "number was pervades all areas of mathematics" [3]. Diperoleh kesimpulan bahwa konsep bilangan harus dipelajari dan dipahami oleh setiap pembelajar, salah satunya adalah konsep bilangan bulat. Bahkan menurut NCTM bahwa "young children focus on whole numbers with which they count, compare quantities, and develop an understanding of the structure of the base-ten number system" [2]. Fokus materi bilangan bulat yaitu keterampilan menghitung seperti memahami letak atau posisi bilangan bulat, serta memahami sifat-sifat operasi hitung bilangan bulat, dan mampu menyelesaikannya secara tepat seperti menjumlahkan dan mengurangkan bilangan bulat. Materi bilangan bulat menjadi dasar yang dibutuhkan untuk berhasil dalam mempelajari aljabar dan penguasaan matematika tingkat tinggi lainnya [4].

Faktanya pada proses perkuliahan, banyak mahasiswa yang masih mengalami kesulitan untuk menyelesaikan permasalahan terkait bilangan bulat. Bahkan untuk operasi hitung dasar seperti penjumlahan dan pengurangan dengan bilangan sederhana masih banyak ditemukan kesalahan atau miskonsepsi. Hal tersebut menunjukkan bahwa penguasaan dan pemahaman konsep bilangan bulat masih rendah. Ketika dibantu menggunakan media koin bilangan pun banyak mahasiswa yang masih keliru. Misalnya, operasi hitung pengurangan bilangan negatif seperti $-4-5=\cdots$ Beberapa mahasiswa menjawab hasilnya adalah -1 . Sehingga didapatkan kesimpulan bahwa mahasiswa masih keliru di dalam memahami suatu konsep. Hal tersebut yang dinamakan dengan miskonsepsi. Miskonsepsi adalah suatu jenis kesalahan dalam memahami setiap konsep matematika dan menyelesaikan masalah matematis [5].

Miskonsepsi dalam suatu pelajaran apapun dapat menjadikan masalah yang tidak bisa dianggap sepele. Terlebih lagi jika berkaitan dengan kemampuan hitung dasar seperti pada pelajaran matematika. "Understanding the wrong prerequisite concept can lead to misconceptions"[6]. Satu kekeliruan atau kesalahan kecil di dalam memahami atau memaknai konsep maka akan mengakibatkan kekeliruan yang terus berlanjut. Terlebih lagi jika materi tersebut menjadi suatu kemampuan prasyarat yang harus dikuasai mahasiswa untuk bisa paham terhadap materi lanjutan. Hal ini tentu akan mengakibatkan kesalahan yang fatal.

Dengan demikian, maka tujuan penelitian ini adalah untuk mengetahui dan mendeskripsikan jenis-jenis miskonsepsi yang dialami mahasiswa PGSD Universitas Mataram berkaitan dengan konsep bilangan bulat terutama operasi hitung bilangan bulat, sampai pada faktor-faktor yang menjadi penyebab terjadinya miskonsepsi tersebut. Jenis-jenis miskonsepsi tersebut selanjutnya dikelompokkan menjadi 3, yaitu: 1) Careless errors atau kesalahan kecerobohan; 2) Concept errors atau kesalahan konsep; dan 3) Careless errors dan Concept errors $(\mathrm{Ca}$ and $\mathrm{Co})$ [7]. Careless errors $(\mathrm{Ca})$ atau kesalahan kecerobohan, yaitu kesalahan yang disebabkan kecerobohan ketika menyelesaikan soal. Misalnya ceroboh dalam mengoperasikan algoritma, ceroboh dalam menuliskan hasil atau jawaban soal. Concept errors (Co) atau kesalahan konsep, yaitu kesalahan yang dilakukan ketika tidak memahami sifat, konsep, definisi atau prinsip matematika yang dapat digunakan untuk menyelesaikan soal. Careless errors dan Concept errors ( $\mathrm{Ca}$ and $\mathrm{Co}$ ), yaitu kesalahan yang berkaitan dengan ketelitian dan kesalahan penggunaan konsep bilangan bulat dalam menyelesaikan soal. 


\section{METODOLOGI PENELITIAN}

Penelitian ini adalah penelitian deskriptif kualitatif yang dilaksanakan pada bulan November 2019 dengan subjek penelitian adalah 45 mahasiswa PGSD Universitas Mataram kelas 3E Sore Tahun Ajaran 2019/2020. Pelaksanaannya adalah seluruh subjek penelitian diberi tes uraian dengan tujuan untuk mendeteksi mahasiswa mana yang mengalami miskonsepsi mengenai materi operasi hitung bilangan bulat, serta mengetahui jenis kesalahan atau miskonsepsi yaitu Careless errors (Ca), Concept errors (Co), serta Careless errors dan Concept errors ( $\mathrm{Ca}$ an $\mathrm{Co})$.

Proses reduksi data dilakukan dengan tujuan untuk menghindari informasi yang sama dari jawaban mahasiswa. Reduksi data diperoleh dengan cara menghitung jumlah mahasiswa yang menjawab benar dan menjawab salah pada masing-masing soal. Data yang dianalisis lebih lanjut adalah jawaban mahasiswa yang salah. Selanjutnya, dianalisis kembali tentang bagaimana cara mahasiswa tersebut dalam menjawab. Cara atau penyelesaian jawaban mahasiswa yang memiliki kesamaan hanya akan diwakilkan satu atau dua saja dari jawaban tersebut.

\section{HASIL DAN PEMBAHASAN}

\section{Hasil Penelitian}

Penelitian dilakukan pada 45 mahasiswa program studi Pendidikan Guru Sekolah Dasar Universitas Mataram kelas 3E yang menempuh mata kuliah Pembelajaran Matematika SD. Mahasiswa menyelesaikan enam soal uraian materi operasi hitung bilangan bulat. Adapun deskripsi indikatornya adalah sebagai berikut: soal 1 terkait dengan operasi pengurangan bilangan positif dengan negatif; soal 2 terkait dengan operasi penjumlahan bilangan positif dengan negatif; soal 3 adalah operasi pengurangan bilangan negatif dengan positif; soal 4 adalah operasi pengurangan bilangan negatif dengan negatif; soal 5 adalah operasi penjumlahan bilangan negatif dengan positif, dan soal 6 adalah pengurangan bilangan positif dengan positif. Khusus untuk soal 3 dan 4, mahasiswa diminta untuk menyelesaikannya menggunakan representasi koin bilangan. Penggunaan koin bilangan dapat membantu pembelajar untuk menerjemahkan antara bentuk representasional bergambar dan tertulis untuk penjumlahan dan pengurangan bilangan bulat [8].

Fokus utama pada penelitian ini adalah menganalisis miskonsepsi dan jenis-jenis miskonsepsi atau kesalahan yang dilakukan mahasiswa di dalam menyelesaikan masing-masing soal yang dikerjakan. Adapun persentase banyaknya mahasiswa yang melakukan kesalahan pada masing-masing soal, ditampilkan seperti Tabel 1.

Tabel 1. Persentase Jawaban Mahasiswa pada Setiap Indikator

\begin{tabular}{|c|c|c|c|c|c|c|c|}
\hline \multirow[b]{2}{*}{ No. } & \multirow[b]{2}{*}{ Soal } & \multirow{2}{*}{$\begin{array}{c}\text { Jawaban } \\
\text { Benar } \\
\mathrm{N}=45\end{array}$} & \multirow{2}{*}{$\begin{array}{c}\text { Jawaban } \\
\text { Salah } \\
\mathrm{N}=45\end{array}$} & \multirow{2}{*}{$\begin{array}{c}\text { Tidak } \\
\text { Menjawab } \\
\mathrm{N}=45\end{array}$} & \multicolumn{3}{|c|}{ Persentase } \\
\hline & & & & & $\begin{array}{c}\text { Jawaban } \\
\text { Benar }\end{array}$ & $\begin{array}{c}\text { Jawaban } \\
\text { Salah }\end{array}$ & $\begin{array}{c}\text { Tidak } \\
\text { Menjawab }\end{array}$ \\
\hline 1. & $125-(-64)$ & 38 & 7 & 0 & $84 \%$ & $16 \%$ & $0 \%$ \\
\hline 2. & $49+(-75)$ & 31 & 13 & 1 & $69 \%$ & $29 \%$ & $2 \%$ \\
\hline 3. & $-8-4$ & 14 & 31 & 0 & $31 \%$ & $69 \%$ & $0 \%$ \\
\hline 4. & $-12-(-5)$ & 10 & 35 & 0 & $22 \%$ & $78 \%$ & $0 \%$ \\
\hline 5. & $-24+95$ & 21 & 20 & 4 & $47 \%$ & $44 \%$ & $9 \%$ \\
\hline 6. & $24-67$ & 21 & 22 & 2 & $47 \%$ & $49 \%$ & $4 \%$ \\
\hline
\end{tabular}

Terkait hasil analisis miskonsepsi atau kesalahan mahasiswa, didapatkan 3 jenis kesalahan yaitu Careless errors ( $\mathrm{Ca}$ ), Concept errors ( $\mathrm{Co}$ ), dan Careless and Concept error (Ca and Co). Adapun persentase banyak siswa pada masing-masing jenis miskonsepsi disajikan pada Tabel 2 di bawah ini. 
Jurnal Ilmiah KONTEKSTUAL, Volume. 2, No..01, Agustus 2020, pp. 15-21

Tabel 2. Persentase Jenis Miskonsepsi Mahasiswa

\begin{tabular}{|c|c|c|c|c|c|c|c|}
\hline \multirow[b]{2}{*}{ No. } & \multirow[b]{2}{*}{ Soal } & \multicolumn{3}{|c|}{ Jumlah siswa yang melakukan miskonsepsi } & \multicolumn{3}{|c|}{$\begin{array}{c}\text { Persentase siswa yang melakukan } \\
\text { miskonsepsi }\end{array}$} \\
\hline & & $\begin{array}{c}\text { Careless } \\
\text { errors }(\mathrm{Ca})\end{array}$ & $\begin{array}{c}\text { Concept } \\
\text { errors (Co) }\end{array}$ & $\begin{array}{c}\text { Careless and } \\
\text { Concept error } \\
(\mathrm{Ca} \text { and } \mathrm{Co})\end{array}$ & $\begin{array}{c}\text { Careless } \\
\text { errors } \\
(\mathrm{Ca}) \\
\end{array}$ & $\begin{array}{c}\text { Concept } \\
\text { errors } \\
(\mathrm{Co}) \\
\end{array}$ & $\begin{array}{l}\text { Careless and } \\
\text { Concept error } \\
(\mathrm{Ca} \text { and } \mathrm{Co})\end{array}$ \\
\hline 1. & $125-(-64)$ & 0 & 9 & 0 & $0 \%$ & $20 \%$ & $0 \%$ \\
\hline 2. & $49+(-75)$ & 2 & 11 & 0 & $4 \%$ & $24 \%$ & $0 \%$ \\
\hline 3. & $-8-4$ & 1 & 24 & 0 & $2 \%$ & $53 \%$ & $0 \%$ \\
\hline 4. & $-12-(-5)$ & 1 & 24 & 1 & $2 \%$ & $53 \%$ & $2 \%$ \\
\hline 5. & $-24+95$ & 0 & 14 & 0 & $0 \%$ & $31 \%$ & $0 \%$ \\
\hline 6. & $24-67$ & 1 & 8 & 3 & $2 \%$ & $18 \%$ & $7 \%$ \\
\hline
\end{tabular}

\section{Pembahasan}

Berdasarkan data pada Tabel 1, terdapat variasi miskonsepsi atau kesalahan pada soal yang dikerjakan mahasiswa. Jika diamati dari kelima soal, kesalahan yang terbanyak ada pada soal nomor 3 dan 4 . Soal nomor 3 ada sebanyak 31 mahasiswa dengan persentase sebesar $69 \%$. Kesalahan terbanyak pertama yaitu ada pada soal nomor 4, yaitu sebanyak 35 mahasiswa dengan persentase sebesar $78 \%$. Soal 3 dan 4 terkait dengan bentuk operasi hitung pengurangan bilangan negatif. Hal tersebut menjelaskan bahwa mahasiswa belum begitu memahami dengan baik tentang penggunaan bilangan negatif. Terlebih lagi pada kedua soal tersebut, mahasiswa diminta untuk menyelesaikan menggunakan representasi gambar koin bilangan. Pada dasarnya karena mahasiswa sendiri belum paham betul mengenai konsep bilangan negatif, ditambah lagi jika harus dituntut menggunakan koin bilangan. Padahal fungsi koin bilangan itu sendiri adalah merepresentasikan soal ke dalam bentuk koin bilangan tujuannya agar lebih konkret. Tetapi kenyataannya tidaklah demikian.

Sebaliknya berdasarkan Tabel 1. di atas, jika dilihat dari jawaban mahasiswa yang menjawab benar maka soal nomor 1 mendapatkan persentase jawaban yang paling tertinggi yaitu sebesar $84 \%$. Dengan kata lain ada mahasiswa sebanyak 38 yang menjawab benar. Setelah dianalisis pada lembar jawaban mahasiswa, penyelesaian untuk soal 1 yaitu $125-(-64)=189$ diselesaikan dengan cara menjumlahkan bilangannya saja. Mahasiswa menyimpulkan bahwa "negatif ketemu negatif" maka hasilnya positif, atau dengan kata lain minus ketemu minus hasilnya plus. Dengan asumsi seperti itu, maka mahasiswa tinggal menjumlahkan kedua bilangan itu saja $(125+64)$, sehingga didapatkan 189 .

Berdasarkan pada Tabel 2. di atas, untuk jenis kesalahan Careless errors $(\mathrm{Ca})$, setelah dianalisis dari hasil jawaban rata-rata letak kesalahan berada pada ketidaktelitian mahasiswa ketika menuliskan kembali soal. Misalnya, mahasiswa tidak hati-hati untuk menulis lambang bilangan dan menulis tanda operasi hitung bilangan. Seperti pada contoh soal nomor 2, pada soal tertulis operasi hitung $49+(-75)$; tetapi ketika mahasiswa menuliskan kembali pada lembar jawaban, lambang bilangan yang tertulis menjadi berbeda, seperti mahasiswa A menulis $49+(-$ 74) dan mahasiswa B menuliskan menjadi $49+(-7)$.

$$
49+(-75)=49+(-74)
$$

Gambar 1. Jawaban soal 2 oleh mahasiswa A

$$
49+(-75)=49+(-7)
$$

Gambar 2. Jawaban soal 2 oleh mahasiswa B 
Dua contoh mahasiswa tersebut, letak miskonsepsinya terletak pada menuliskan lambang bilangan. Selain itu, ada juga mahasiswa yang salah menuliskan operasi hitung bilangan. Seperti pada contoh soal 3 dan 6 .

$$
-8-4=-8+4
$$

Gambar 3. Jawaban soal 3 oleh mahasiswa C

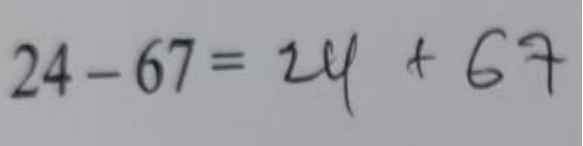

Gambar 4. Jawaban soal 6 oleh mahasiswa D

Pada soal 3 tertulis $-8-4$, tetapi ditulis menjadi $-8+4$. Selanjutnya untuk soal 6 yang seharusnya ditulis $24-67$, tetapi ada satu orang mahasiswa yang menuliskannya menjadi operasi bentuk penjumlahan menjadi $24+67$. Jika dianalisis jenis miskonsepsi mahasiswa untuk kategori Careless errors $(\mathrm{Ca})$ hanya disebabkan oleh dua kekeliruan seperti yang dideskripsikan di atas, dan frekuensi banyaknya mahasiswa menjawab salah, antara 1 sampai 2 orang saja atau terletak diantara rentang $2 \%$ sampai $4 \%$.

Miskonsepsi untuk jenis Concept errors (Co), persentase mahasiswa yang mengalami kesalahan untuk setiap nomor soal ada di rentang antara 18\% sampai 53\% atau masing-masing soal paling sedikit ada 8 mahasiswa untuk soal 6 dan paling banyak ada 24 mahasiswa untuk soal 3 dan 4. Jika dianalisis lebih lanjut indikator soal 3 dan 4 terkait dengan operasi pengurangan bilangan negatif. Khusus untuk soal 3 dan 4, peneliti khusus meminta mahasiswa untuk dapat menyelesaikannya menggunakan alat bantu media koin bilangan, yang selanjutnya direpresentasikan dalam bentuk gambar. Tujuannya agar membantu mahasiswa menyadari tentang kenegatifan bilangan hasil operasi khususnya operasi hitung bilangan bulat negatif [9]. Selain itu, penggunaan koin bilangan ditujukan untuk membantu merepresentasikan dan mengkongkretkan operasi hitung bilangan negatif yang dimaksud pada soal. Hal tersebut dengan alasan bahwa mahasiswa sebelumnya sudah diperkenalkan dengan penggunaan media koin bilangan, selain garis bilangan di dalam mempelajari bilangan bulat pada perkuliahan pembelajaran matematika SD. Tetapi praktiknya, beberapa mahasiswa melakukan miskonsepsi. Adapun letak miskonsepsi di dalam penyelesaian operasi hitung bilangan menggunakan koin bilangan adalah sebagai berikut:

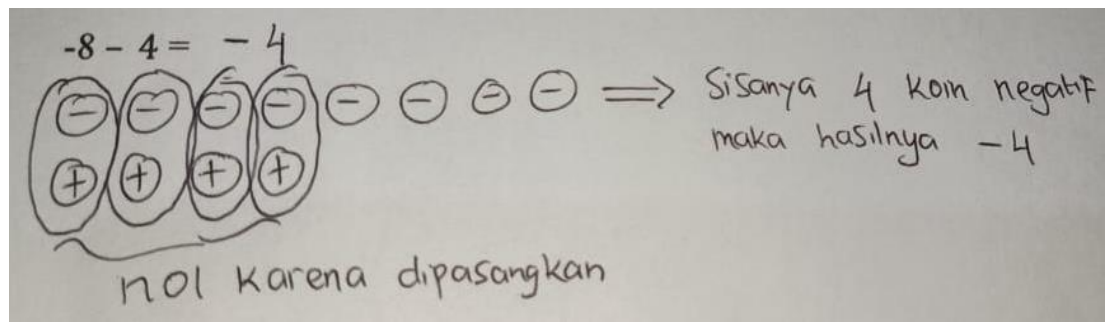

Gambar 5. Jawaban untuk soal 3 oleh mahasiswa E

Pada soal 3 dengan indikator operasi pengurangan bilangan negatif dengan positif seperti $-8-4$, mahasiswa tersebut menjawab -4 . Mahasiswa menggambarkan delapan koin negatif untuk merepresentasikan -8, dan empat koin positif untuk merepresentasikan bilangan 4 . Satu koin positif dan satu koin negatif jika dipasangkan maka akan bernilai nol. Dikarenakan ada empat koin pasangan bernilai nol (0) dan tersisa empat koin negatif, maka hasil dari operasi hitung bilangannya adalah -4 . Atau dengan kata lain penyelesaiannya dengan cara $8-4$ didapatkan jawaban 4. Sedangkan untuk tanda negatifnya (-) hanya mengikuti saja, tinggal 
Jurnal Ilmiah KONTEKSTUAL, Volume. 2, No..01, Agustus 2020, pp. 15-21

dilengkapi menjadi -4. Itulah miskonsepsi yang dilakukan oleh mahasiswa E. Begitu juga untuk indikator operasi hitung pengurangan bilangan sesama negatif (pada soal 4), ada sebanyak 24 mahasiswa atau sekitar 53\% yang juga mengalami miskonsepsi. Miskonsepsi pada penyelesaian operasi hitung bilangan bulat dapat terjadi karena mahasiswa hanya menghafalkan konsep semata tanpa memperhatikan hubungan yang ada pada antar konsep [10].

Sementara untuk jenis kesalahan Careless and Concept error ( $\mathrm{Ca}$ and $\mathrm{Co}$ ) hanya ada 4 mahasiswa saja yang mengalami miskonsepsi, khusus untuk soal 4 dan 6 dengan masingmasing soal 1 sampai 3 mahasiswa saja. Soal 4 berkaitan dengan indikator pengurangan bilangan negatif dengan negatif yaitu $-12-(-5)$. Jenis miskonsepsi Careless error (Ca) dilakukan mahasiswa karena keliru di dalam menuliskan kembali bilangan pengurangnya dari -5 menjadi -15 , maka dalam hal ini akan mempengaruhi hasil operasi hitungnya.

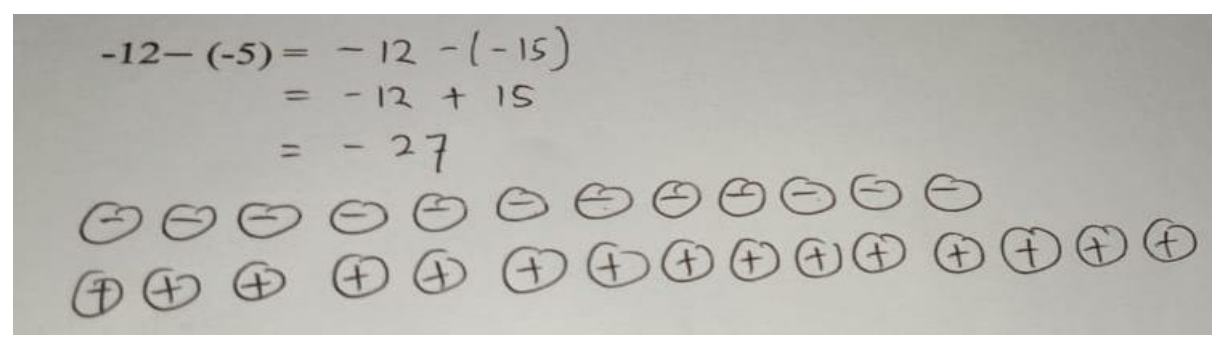

Gambar 6. Jawaban untuk soal 4 oleh mahasiswa F

Pada soal 4 tersebut, mahasiswa diminta untuk menyelesaikan dengan mengilustrasikan menggunakan media koin bilangan. Dari sinilah muncul miskonsepsi jenis Concept error (Co), yaitu mahasiswa tidak memahami dengan benar konsep pengurangan bilangan bulat. Mahasiswa menuliskan -27 sebagai hasil operasi hitung antara -12-(-15). Ditambah lagi cara penyelesaian menggunakan media koin bilangan hanya sebatas merepresentasikan soalnya saja (ada koin negatif sebanyak 12 dan koin positif sebanyak 15, sedangkan jawabannya kembali lagi pada pengetahuan mahasiswa "jika min ketemu min maka menjadi plus, atau jika negatif ketemu negatif maka akan menjadi positif", tanpa menghiraukan jenis tanda bilangan yang dikurangi yaitu -12. Miskonsepsi tersebut dikarenakan pemahaman konseptual mahasiswa akan tanda negatif yang kurang tepat penggunaannya [11].

Jenis miskonsepsi Careless and Concept error ( $\mathrm{Ca}$ and $\mathrm{Co}$ ) yang dilakukan mahasiswa juga terdapat pada soal 6 berupa operasi pengurangan bilangan positif dengan positif dengan $a<b$ yaitu 24-67. Miskonsepsi atau jenis Careless error (Ca) dilakukan dengan keliru menuliskan kembali soal yang diberikan menjadi 24-64. Selanjutnya untuk Concept error (Co), mahasiswa salah di dalam memberikan jawaban menjadi -88. Hal tersebut mengartikan bahwa untuk miskonsepsi jenis ini, mahasiswa masih kurang teliti di dalam membaca soal, kurang teliti di dalam menuliskan kembali soal, serta belum paham terhadap konsep pengurangan bilangan bulat yang meliputi pengurangan bilangan bulat yang sejenis, yaitu negatif dengan negatif dan positif dengan positif dimana $(a<b)$.

\section{SIMPULAN}

Miskonsepsi matematika mahasiswa PGSD sebagai calon guru sekolah dasar pada penyelesaian operasi hitung bilangan bulat dibedakan menjadi 3 jenis, yaitu Careless error (Ca), Concept error (Co), dan Careless and Concept error ( $\mathrm{Ca}$ and $\mathrm{Co}$ ). Persentase jumlah mahasiswa yang melakukan miskonsepsi Careless error (Ca) sebesar 10\% (5 mahasiswa) dari total 6 soal yang diberikan. Kesalahan yang dilakukan berupa tidak teliti di dalam menuliskan kembali komponen soal yang diberikan. Mahasiswa salah di dalam menuliskan lambang bilangan yang dimaksud atau salah dalam memberikan lambang positif atau negatif dari bilangan bulat, maupun salah menulis tanda operasi hitung bilangan.

Mahasiswa paling banyak melakukan kesalahan dengan jenis Concept error (Co) sejumlah 24 mahasiswa dengan persentase sebesar 53\%. Letak kesalahannya adalah mahasiswa tidak 
Jurnal Ilmiah KONTEKSTUAL, Volume. 2, No..01, Agustus 2020, pp. 15-21

memahami dengan benar aturan dan prinsip di dalam penyelesaian operasi hitung bilangan bulat positif maupun negatif. Terkadang mahasiswa mengabaikan lambang positif atau negatif dari bilangan bulat, sehingga mengganggap seakan tidak ada beda di antara keduanya. Selanjutnya sebanyak 4 mahasiswa dengan persentase sebesar 9\% dari total 6 soal yang diberikan melakukan miskonsepsi jenis Careless and Concept error ( $\mathrm{Ca}$ and $\mathrm{Co}$ ). Careless and Concept error ( $\mathrm{Ca}$ and $\mathrm{Co}$ ) adalah kekeliruan atau kurang hati-hati pada saat membaca dan menuliskan kembali soal dan kesalahan konsep ketika menyelesaikan operasi hitung bilangan bulat yang meliputi pengurangan bilangan bulat yang sejenis, yaitu negatif dengan negatif dan positif dengan positif.

\section{REFERENCES}

[1] Marsigit, Pendidikan Karakter dalam Perspektif Teori dan Praktik, Pengembangan Karakter dalam Pendidikan Matematika, 2011, UNY Press, Yogyakarta.

[2] Yuliyanti, N \& Sunarsih, D, "Pengaruh Model Cooperative Tipe TGT Terhadap Kemampuan Berpikir Kritis Matematika Siswa Kelas IV," Jurnal Ilmiah Kontekstual, vol. 1, no.1, pp. 45-53, 2019, [Online]. Available: http://jurnal.umus.ac.id/index.php/kontekstual/article/view/58/40

[3] National Council of Teacher of Mathematics (NCTM), Principles and Standards for School Mathematics, 2000, Association Drive, Reston.

[4] M. Khalid and Z. Embong, "Source and possible causes of errors and misconceptions in operations of integers," IEJME, International Electtonic Journal of Mathematics Education., vol. 15, no. 2, pp 1-13, 2020, [Online]. Available: http://doi.org/10.29333/iejme/6265

[5] J. P. Purwaningrum and H. S. Bintoro, "Miskonsepsi matematika materi bilangan pada mahasiswa calon guru sekolah dasar," Prosiding Seminar Nasional MIPA., vol. 1, no. 1, pp 173-180, 2019, [Online]. Available: https://proceeding.unnes.ac.id/index.php/SNMIPA/article/view/193

[6] D. Permata., P Wijayanti., and Masyariah, "Students' misconceptions on the algebraic prerequisites concept: operation of integer numbers and fractions," Journal of Physics: Conf. Series., pp 1-17, 2019, [Online]. Available: https://iopscience.iop.org/article/10.1088/1742-6596/1188/1/012059/meta

[7] L. Badriyah., A. R. As'ari., and H. Susanto, "Profil kesalahan siswa smp dalam menyelesaikan operasi hitung bilangan bulat," pp 485-491, 2017, [Online]. Available: http://www.researchgate.net/publication/313058147

[8] J. Bolyard, and P. M. Packenham, "Making sense of integer Arithmetic: The effect of using virtual manipulatives on students' represent-tational fluency," Journal of Computers in Mathematics and Science Teaching., vol. 31, no. 2, pp 93-113, 2012, [Online]. Available: https://learntechlib.org/p/39192/

[9] L. Badriyah., A. R. As'ari., and H. Susanto, "Analisis kesalahan dan scaffolding siswa berkemampuan rendah dalam menyelesaikan operasi tambah dan kurang bilangan bulat," Jurnal Pendidikan: Teori, Penelitian, dan Pengembangan., vol. 2, no. 1, pp 5057, 2017, [Online]. Available: http://journal.um.ac.id/index.php/jptpp/article/view/8403

[10] U. Fatmahanik, "Penelusuran miskonsepsi operasi bilangan bulat dalam pembelajaran matematika pada mahasiswa pgmi dengan menggunakan cri (certainly of respon index)," Cendekia: Jurnal Kependidikan dan Kemasyarakatan., vol. 16, no. 1, pp 167187, 2018, [Online]. Available: https://jurnal.iainponorogo.ac.id/index.php/cendekia

[11] R. Kurniati., Ruslan., and H. Ihsan, "Miksonsepsi siswa sekolah menengah pertama (SMP) terhadap bilangan bulat, operasi dan sifat-sifatnya." Inteligensi Jurnal Ilmu Pendidikan., vol. 1, no. 1, pp 1-17, 2018, [Online]. Available: https://jurnal.unitri.ac.id/index.php/inteligensi/article/view/1137 